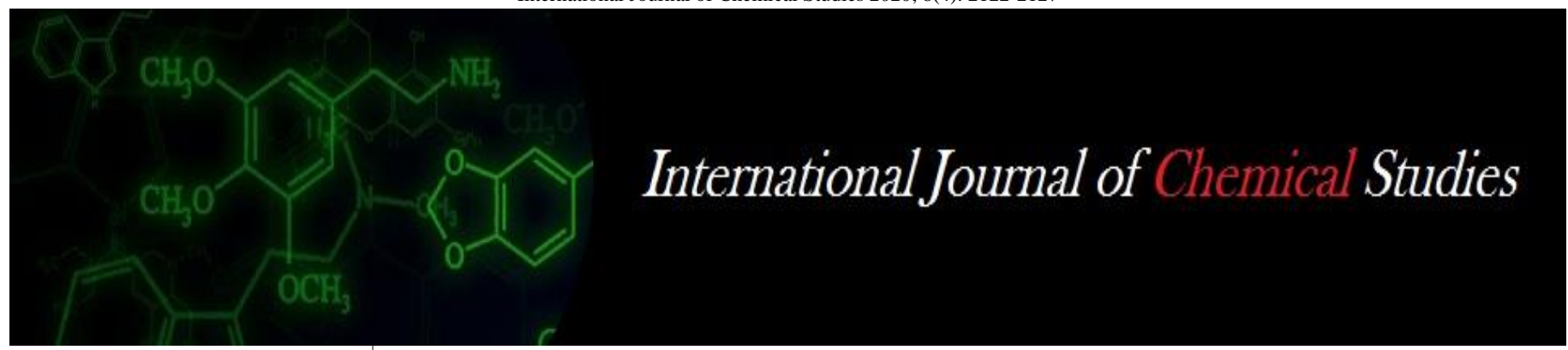

P-ISSN: 2349-8528

E-ISSN: 2321-4902

www.chemijournal.com

IJCS 2020; 8(4): 2122-2127

(C) 2020 IJCS

Received: 14-05-2020

Accepted: 16-06-2020

\section{JM Vashi}

Department of Vegetable Science ASPEE College of Horticulture and Forestry Navsari

Agricultural University, Navsari, Gujarat, India

\section{SN Saravaiya}

Department of Vegetable Science ASPEE College of Horticulture and Forestry Navsari

Agricultural University, Navsari, Gujarat, India

\section{AI Patel}

Department of Vegetable Science ASPEE College of Horticulture and Forestry Navsari Agricultural University, Navsari, Gujarat, India

\section{BN Chaudhari}

Department of Vegetable Science ASPEE College of Horticulture and Forestry Navsari

Agricultural University, Navsari, Gujarat, India
Corresponding Author: JM Vashi

Department of Vegetable Science ASPEE College of Horticulture and Forestry Navsari

Agricultural University, Navsari, Gujarat, India

\section{Silicon - The most under-appreciated element for vegetables}

\section{JM Vashi, SN Saravaiya, AI Patel and BN Chaudhari}

DOI: https://doi.org/10.22271/chemi.2020.v8.i4w.9941

\begin{abstract}
Silicon ( $\mathrm{Si}$ ) has not been recognized as an essential element for plant growth but beneficial effects of Si have been observed in a wide variety of plant species. The positive effects of $\mathrm{Si}$ are usually expressed more clearly in Si-accumulating plants under various biotic stress conditions. Silicon is effective in controlling various pests and diseases caused by both fungi and bacteria in different plant species. Silicon also exerts alleviative effects on various abiotic stresses including salt stress, metal toxicity, drought stress, radiation damage, nutrient imbalance, high temperature, freezing and so on. These beneficial effects are mainly attributed to the high accumulation of silica on the tissue surface although other mechanisms have also been proposed. This review paper is tribute to understand different aspects of silicon viz., silicon absorption by plants, reaction of silicon in soil, silicon transport and content in plants,sources of silicon and beneficial effects of silicon furthermore review of research work for vegetable crop production also included.
\end{abstract}

Keywords: Silicon under-appreciated vegetables essential element

\section{Introduction}

Vegetables are so common in human diet that a meal without a vegetable is supposed to be incomplete in any part of the India. Vegetables are important food and highly beneficial for the maintenance of health and prevention of diseases. They contain valuable food ingredients which can be successfully utilized to build up and repair the body. India is the second largest producer of vegetables in the world, next to China. These are grown in about 6 million hectares forming $3 \%$ of the total cropped area. Though the vegetable requirement is $300 \mathrm{~g} / \mathrm{day} / \mathrm{person}$ as recommended by dietician, we are able to meet about $1 / 9^{\text {th }}$ of that requirement only. Looking at the national scenario, vegetables have tremendous strength in terms of natural resources and biological assets especially genetic resources. Large number of wild taxa of indigenous vegetables are available in the different agro-ecological zones of the country and hardly some of them have been capitalized. This needs further attention and efforts to develop varieties resistant to biotic and abiotic stresses. India has to go a long way to accelerate the vegetable production, considering the national and international demand. There is a need to achieve the target of 225 million tonnes by the end of 2020 and 350 million tonnes by 2030 . In all this circumstances the beneficial element Silicon and it's uses particular for vegetable crops may prove the solution or answers for many questions regarding vegetable production. Silicon role for vegetable production was overlooked or under-appreciated but the beneficial effects of this element on growth, yield, quality and disease resistance have been observed in wide range of research on vegetables.

\section{Silicon Absorption by Plants}

Plants absorb silicon from the soil solution in the form of monosilicic acid, also called orthosilicic acid [H4SiO4].The largest amount of silicon is absorbed by sugarcane (300-700 $\mathrm{kg}$ of Si ha-1), followed by rice $(150-300 \mathrm{~kg}$ of Si ha-1), and wheat (50-150 kg of Si ha-1) (Bazilevich.1993) ${ }^{[3]}$. On an average, plants absorb from 50 to $200 \mathrm{~kg}$ of Si ha ${ }^{-1}$. Such values of absorbed silicon cannot be fully explained by passive absorption (such as diffusion or mass flow) because the upper $20 \mathrm{~cm}$ soil layer contains only an average of $0.1-1.6 \mathrm{~kg} \mathrm{Si}$ ha-1 as monosilicic acid (Matichenkov et al., 1997\&2000) ${ }^{[34,35]}$. Results have shown that rice roots possess specific ability to concentrate silicon from the external solution 
(Takahashi et al., 1995) ${ }^{[44]}$. Yoshida et al., $1975^{[48]}$ revealed that rice plant absorbs silica in the form of ortho-silicic acid ( $\mathrm{H} 4 \mathrm{SiO} 4$ or $\mathrm{Si}(\mathrm{OH}) 4)$ along with water from the growing medium and the water is lost through transpiration. Because of continued absorption and transpiration, the Si concentration increases and at higher levels ortho-silicic acid polymerizes into silica gel ( $\mathrm{SiO} 2$ nH2O) through a non-enzymatic reaction.

\section{Chemical reactions of silicon in the soil}

Silicon produces by the weathering processes of primary and secondary minerals including clay silicates in the soil. The main sources of silicon in soil solution are the decomposition of plant residues, dissociation of polymeric $\mathrm{H} 4 \mathrm{SiO} 4$, release of silicon from iron and aluminium oxides and hydroxides, dissolution of non-crystalline and crystalline minerals and addition of silicon fertilizers. Silicon fertilizers are mostly neutral or slightly alkaline in biochemical nature. The most available form of silicon is found in the soil solution is silicic or monosilicic acid (H4SiO4) a non-charged molecule, which can be easily absorbed by the plants.

\section{Reactions \\ $\mathrm{CaSiO} 3+\mathrm{H} 2 \mathrm{O} \leftrightarrow \mathrm{Ca} 2++\mathrm{SiO} 3-2+\mathrm{H} 2 \mathrm{O}$ \\ $\mathrm{SiO} 3-2+2 \mathrm{H}-\leftrightarrow \mathrm{H} 2 \mathrm{SiO} 3$ \\ $\mathrm{H} 2 \mathrm{SiO} 3+\mathrm{H} 2 \mathrm{O} \leftrightarrow \mathrm{H} 4 \mathrm{SiO} 4$}

Sandy soils are low in silicon in the upper horizons but clay soils show higher concentrations of phyllosilicates (minerals that release $\mathrm{Si}$ and $\mathrm{Al} 3+$ ) and silicon in comparison to sandy soils.

\section{Silicon Transport in Plants}

In the plant, silicon is transported from the root to shoot by the transportation stream in the xylem. Soluble monosilicic acid may penetrate through cell membranes passively. After root adsorption, monosilicic acid is translocated rapidly into the leaves of the plant in the transpiration stream (Ma.2006) [31]. Silicon is concentrated in the epidermal tissue as a fine layer of silicon-cellulose membrane and is associated with pectin and calcium ions. By this means, the double-cuticular layer can protect and mechanically strengthen plant structures. With increasing Si concentration in the plant sap, monosilicic acid is polymerized. The chemical nature of polymerized silicon has been identified as silicon gel or biogenic opal, amorphous $\mathrm{SiO} 2$, which is hydrated with water molecules. Monosilicic acid polymerization is assigned to the type of condensable polymerization with gradual dehydration of monosilicic acid and then polysilicic acid. Plants synthesize silicon-rich structures of nanometric (molecular), microscopic (ultrastructural), and macroscopic (bulk) dimensions. 90\% of absorbed silicon is transformed into various types of phytoliths or silicon-cellulose structures, represented by amorphous silica. Partly biogenic silica is generated as unique cell or inter-cell structures at the nanometer level.

\section{Silicon Content of plant}

The content of silica in plants is equivalent to or more than the major nutrients N, P, K supplied through fertilizers.Higher plants differ characteristically in their capacity to take up silicon (Marschner.1996) ${ }^{[32]}$. Some plants absorb more silica than they require and this gets deposited on tissues as it cannot be excreted (Esan.1953) ${ }^{[13]}$. Depending on their SiO2 content expressed as a percentage of shoot dry weight (SDW), they can be divided into three major groups: wetland Gramineae, such as wetland rice or horsetails (Equisetum),
10-15\%; dryland Gramineae, such as sugarcane and most of the cereal species and a few dicotyledons, 1-3\%; and most dicotyledons, especially legumes, $<10.5 \%$ (Takahashi et al., 1977) ${ }^{[42]}$. Among the plants, silica concentration is found to be higher in monocotyledons than in dicotyledons and its level shows an increase from legumes $<$ fruit crops $<$ vegetables $<$ grasses $<$ grain crops (Thiagalingam et al., 1977) ${ }^{[45]}$. The aerial plant parts accumulate more Si than roots. In general the Si content of shoots tend to decline in following order; liver worts $>$ horse tails $>$ club mosses $>$ mosses $>$ angiosperms $>$ gymnosperms $>$ ferns (Hodson et al., 2005) ${ }^{[18]}$. Grasses accumulate $2-20 \%$ foliar dry weight as hydrated polymer or silica gel.

\section{Sources of Silicon}

Although silicon is a very abundant element, for a material to be useful as a fertilizer, it must have a relatively high content of silicon, provide sufficient water-soluble silicon to meet the needs of the plant, be cost effective, have a physical nature that facilitates storage and application, and not contains substances that will contaminate the soil (Gascho.2001) ${ }^{[14]}$. Many potential sources meet the first requirement however, only a few meet all of these requirements. Crop residues, especially of silicon-accumulating plants such as rice, are used as silicon sources. However, the crop demand for application of Si fertilizer generally exceeds that which can be supplied by crop residues. Inorganic materials such as quartz, clays, micas, and feldspars, although rich in $\mathrm{Si}$, are poor silicon-fertilizer sources because of the low solubility of the Si. Calcium silicate, obtained as a byproduct of steel and phosphorus production, is one of the most widely used silicon fertilizer. Potassium silicate, though expensive, is highly soluble and can be used in hydroponic culture. Other sources that have been used commercially are calcium silicate hydrate, silicagel, and thermo-phosphate (Gascho.2001) ${ }^{[14]}$. Silicon alleviates certain nutritional disorders like a kiochior bronzing. (Liang et al., 2003) ${ }^{[28]}$ strongly suggested that $\mathrm{Si}$ may be involved in metabolic or physiological and/or structural activity in higher plants exposed to abiotic and biotic stresses.

\section{Effect of Silicon on Biotic Stress}

The Si in plants is found to alleviate many biotic and abiotic stresses, leading to the application of silicates either directly to crops or incorporate it into the fertilizers applied. It does not form a constituent of any cellular component but is primarily deposited on the walls of the epidermis and vascular tissues conferring strength, rigidity and resistance to pests and diseases. The effect of $\mathrm{Si}$ on plant resistance to pests is considered to be due to accumulationof absorbed $\mathrm{Si}$ in the epidermal tissue or expression of pathogensis-induced hostdefense responses. Accumulated monosilicic acid polymerizes into polysilicic acid and then transforms to amorphous silica, which forms a thickened silicon-cellulose membrane and which gets associated with pectin and calcium ions. By this means, a double-cuticular layer protects and mechanically strengthens plants. Silicon might also form complexes with organic compounds in the cell walls of epidermal cells, therefore increasing their resistance to degradation by enzymes released by the rice blast fungus ( $\mathrm{Si}$ gets associated with lignin-carbohydrate complexes in the cell wall of epidermal cells (Inanga et al.,1995) ${ }^{[19]}$.

\section{Disease Resistance}

The mechanism for Si-induced resistance to diseases is due to 
(i) Si acting as a physical barrier and (ii) soluble Si acting as a modulator of host resistance to pathogens. Silicon is deposited beneath the cuticle to form a cuticle-Si double layer which mechanically impede penetration of fungi and thus disrupt the infection process.

A research team in Florida headed by Lawrence Datnoff demonstrated the effectiveness of $\mathrm{Si}$ enrichment in $\mathrm{c}$ ontrollingseveral diseases of warm-season turf grasses. About $30 \%$ of gray leaf spot on St. augustine grass was controlledby $\mathrm{Si}$ applications, and its addition increased the effectiveness of fungicide treatments (Brecht et al.,2001) ${ }^{[5]}$. Common bermudagrass exhibited a doubling of Si content when its growth medium was supplemented with calcium silicate (Datonof et al., 2003) ${ }^{[8]}$. Silicon stimulates chitinase activity and rapid activation of peroxidases and polyphenoxidases after fungal infection (Cherf et al., 1994) ${ }^{\text {[7] }}$ Glycosidically bound phenolics extracted from $\mathrm{Si}$ amended plants when subjected to acid or ß-glucosidase hydrolysis displayed strong fungistatic activity.

\section{Against the Insect -Pest}

The deposition of silica on epidermal layers offers a physical barrier to insects. Sucking pests and leaf eating caterpillars have a low preference for the silicified plant tissues. The incidences of stem maggots, green leaf hopper, brown plant hopper and white backed plant hopper, leaf folder etc. in rice were reduced due to $\mathrm{Si}$ nutrition. Use of ash in the home to control aphids is an old age practice in rural India. Application of $\mathrm{Si}$ to corn affected the infection of the Spodoptera.

\section{Effect on Abiotic Stress}

Silicon nutrition alleviates many abiotic stresses including physical stress like lodging, drought, radiation, high temperature,freezing, UV and chemical stress like salt, metal toxicity, nutrient imbalance and many others (Epstein, E.1994) [11]. It increases drought tolerance in plants by maintaining plant water balance, photosynthetic efficiency, erectness of the leaves and structure of xylem vessels under high transpiration rates due to higher temperature and moisture stress(Hattori et al.,2005) ${ }^{[17]}$. The beneficial effects are attributed to Si deposition in the cell walls of roots, leaves, culms and hulls. Silicon deposits in cell walls of xylem vessels prevent compression of the vessels under conditions of high transpiration caused by drought or heat stress. The silicon cellulose membrane in epidermal tissue protects plants against excessive loss of water by transpiration. This action occurs owing to a reduction in the diameter of stomatal pores and, on sequently, a reduction in leaf transpiration. The Si deposition in roots reduces the binding sites for metals resulting in decreased uptake and translocation of salts and toxic metals from roots to shoot.

There are several hypotheses to combat abiotic stresses viz., (a) improved photosynthetic activity,(b) enhanced $\mathrm{K} / \mathrm{Na}$ selectivity ratio, (c) increased enzyme activity, and (d) increased concentration of soluble substances in the xylem, resulting in limited sodium adsorption by plants. Si alleviated effects have been associated with an increase in antioxidant defense mechanism of plants. There are various types of mechanisms with in the plants to alleviate different stresses. Silicon deposited in the plant tissues helps to alleviate water stress by decreasing transpiration and improves light interception characteristics by keeping the leaf blade erect(Epstein.1999) ${ }^{[12]}$. Accumulation of Si will form a thick silicated layer on the leaf surface which effectively reduces cuticular transpiration. The findings from Japanese researchers revealed that the application of silica will reduce transpiration loss by as much as $30 \%$. A well-thickened layer of silica gel associated with the cellulose in the epidermal cellwalls, which reduces water loss, while an epidermal cellwall with less silica gel will allow water to escape at an accelerated rate (Wong et al., 1972) ${ }^{[47]}$. Kaya et al. (2006) ${ }^{[24]}$ reported that inhibition of plant growth was significantly alleviated by $\mathrm{Si}$ supplement. Under water stress, Si significantly increased the dry weight of shoots and total biomass of maize. Lux et al. (2002) [21] noted that Si applicationin creased growth of Sorghum bicolor, grown under waterstress. Water stress tends to increase biomass partitioningto roots, increasing root: shoot ratio (Klepper. 1991) ${ }^{[25]}$. It reduces leaf concentration of calcium (Ca) and potassium (K) in maizeplants, but the addition of Si increases these nutrient levels; Ca level remains normal in well-watered conditions under the high-Si treatment, but $\mathrm{K}$ was lower. It was also suggestedthat silica in plants filter harmful ultraviolet radiation reaching leaf surface, acting as 'windows' (Tisdale et al., 1985) ${ }^{[41]}$.

Silicon can also alleviate imbalances between zinc and phosphorus supply. Silicon supply increases the photo assimilation of carbon and also promotes the assimilated carbon to the panicle in rice (Takahashi et al., 1982) ${ }^{[43]}$. It is probably the only element which is able to enhance the resistance to multiple stresses. The mechanism of such protection is due to $\mathrm{Si}$ binding with metals and preventing their concentration to toxic levels at localized sites. Iron, manganese and aluminum are the metals most often found to be less toxic in the presence of $\mathrm{Si}$. In $\mathrm{Si}$-accumulator plants, iron and manganese are immobilized within the roots before they can be transported to shoots (Ma et al., 1990) ${ }^{[30]}$. Gong et al,. (2003) ${ }^{[15]}$ reported that application of $\mathrm{Si}$ can increase dry matter (DM) of wheat in well-watered conditions and improve the growth under drought conditions by maintaining high leaf area. It insures high assimilatory capability, thickening leaves which are beneficial to reduce the transpiration loss of water. Therefore, application of Si may be an available pathway to increase production of wheat crop in arid or semi-arid areas. Silicon did not change the relative water content (RWC) and water potential without drought stress. But drought stress decreased them, and they were higher in the presence of added Si than absence. Therefore, Si application could improve the water status under drought conditions. The leaf area was also significantly increased by $\mathrm{Si}$ in the well-watered conditions. Silicon application improved water economy and DM yield of wheat (Korndo et al., 2001) ${ }^{[26]}$.

\section{Effect on Yield}

Silicon fertilizers are applied to crops in several countries for increased productivity and sustainable production. It was found beneficial to barley, wheat, corn, sugarcane, cucumber, citrus, tomato and other crops (Epstein.1999) ${ }^{[12]}$. Several studies have suggested positive growth effects of silicon nutrition, increased biomass, yield and pollination (Kornodor et al., 2001) ${ }^{[27]}$.Application of Si improves growth of maize and increases its production and yield in arid or semi-arid areas underwater-stress conditions (Kaya et al., 2006) ${ }^{[24]}$. Mukhtar et al. (2012) ${ }^{[36]}$ revealed that silicon nutrition has significant effect on crop growth, physiological attributes and yield parameters. The effect was more significant for wheat variety Chakwal-50 under10\% Si application with irrigation as compared to other genotypes under other levels of $\mathrm{Si}$ 
concentrations. It boosted up crop growth and accumulation of more photo assimilates from source to sink and consequently, it led to higher grain yield. Ahmed et al. (2011) [1] found that the increase in silicon leads to increase in leaf area index(LAI), specific leaf weight, chlorophyll content (SPAD), leaf dry weight (LDW), SDW, root dry weight (RDW), total dry weight (TDW) and remarkable decrease in leaf water potential and shoot to root ratio in sorghum cultivars as compared to control treatment. When silicon concentration is applied with irrigation LAI, SPAD, LDW, SDW, RDW, TDW, net assimilation rate, relative growth rate, leaf area ratio and water use efficiency increased by 30 , $31,40,30,28,30,27,35,32,30$ and $36 \%$ respectively as compared to water deficient treatment. These results suggest that silicon application may be useful to improve the drought tolerance of sorghum through the enhancement of water uptake ability. Due to a synergistic effect, applied Si has the potential to raise the optimum rate of $\mathrm{N}$, thus helping to enhance yields (Elawad et al., 1979) ${ }^{[10]}$. Raid et al. (1992) ${ }^{[38]}$ reported an average increase of $20 \%$ in sugarcane yield by the Ca silicate application at 3 tons/acre. Its application benefited both crops in a rice sugarcane rotation when applied prior to rice planting (Hattori et al., 2005) ${ }^{\text {[17] }}$. Sugarcane yield responses to $\mathrm{Ca}$ silicate application ranged from 0 to 9 tons sugar/acre/year with relative yield being reduced to as much as $23 \%$ without application (Anderson et al., 1987) ${ }^{[2]}$. Research findings from China revealed that rice yield of 7.5 $\mathrm{t} / \mathrm{ha}$ require $750-1,500 \mathrm{~kg}$ ha- 1 of silica. On an average, 1,125 $\mathrm{kg}$ ha- 1 of silica is required to achieve that yield. This far exceeds the absorption of the three major plant nutrients namely nitrogen, phosphorous, and potassium. Application of $\mathrm{Si}$ in rice increased the grain yield under both upland and water logged conditions (Datta et al., 1985) ${ }^{[9]}$. The application of silicate augmented its absorption by rice plant other nutrients as well. With adequate $\mathrm{Si}$ the uptake of nitrogen was increased (Sadanandan et al., 1969) [39]. However, decrease in $\mathrm{N}$ content was also reported in rice in response to $\mathrm{Si}$ addition to solution culture (Islam et al., 1969) ${ }^{[20]}$. Greenhouse and field experiments showed benefits of $\mathrm{Si}$ fertilization for rice, barley, wheat, corn, sugarcane, cucumber, tomato, citrus and other crops (Epstein.1999) ${ }^{[12]}$.

\section{Review of research work on Vegetables Growth and yield:}

The effect of two different silicate mineral product was applied as foliar spray treatments during head formation to evaluate head weight of Six Cabbage cultivars and revealed that silicate mineral treatment recorded significantly higher head weight in two cultivars. (Balint et al., 2010) ${ }^{[4]}$.

Application of K-silicate at $1.5 \mathrm{~kg} / \mathrm{Fed}$ resulted in higher stem diameter and maximum RGR, NAR and LWC in Capsicum during both season. (Kamal, 2013) ${ }^{[23]}$.

Jaywardana et al. (2014) ${ }^{[21]}$ noticed that Capsicum recorded significantly higher shoot length, number of leaves, average leaf area, fruit length, fresh weight of fruit and yield per plant with rice hull leachate $+\mathrm{AL}$ and rice hull leachate $+\mathrm{NF}$ treatment over control.

Jing-Kai et al. (2014) ${ }^{[22]}$ measured significantly higher plant fresh weight $(60.04 \mathrm{~g})$, pseudostem length $(12.90 \mathrm{~cm})$, pseudostem diameter $(14.87 \mathrm{~mm})$ and maximum plant height $(58.33 \mathrm{~cm})$ in Garlic with $\mathrm{Si}-1.5$ (mmol/l) treatment. Furthermore, they found significantly higher Chlorophyll a, b and carotenoid content $(0.71 \mathrm{mg} / \mathrm{g}, 0.19 \mathrm{mg} / \mathrm{g}$ and $0.20 \mathrm{mg} / \mathrm{g}$, respectively), stomatal conductance $\left(878.34 \mathrm{mmol} / \mathrm{m}^{2} / \mathrm{s}\right)$ with Si-1.5 (mmol/l) treatment. Transpiration rate $(5.14$ $\mathrm{mmol} / \mathrm{m}^{2} / \mathrm{s}$ ) was also found significantly lower in this treatment.

Olle (2014) ${ }^{[37]}$ studied the effect of silicon on cucumber and found that silicic acid treatment recorded signif icantly 35 per cent higher plant height $(\mathrm{cm})$ and significantly 27 per cent higher stem diameter $(\mathrm{cm})$ than control. He also noticed significantly higher nitrogen and phosphorus content in dry matter of cucumber plant.

Gowda et al. (2015) ${ }^{[16]}$ recorded the maximum plant height $(104.13 \mathrm{~cm}$ and $103.20 \mathrm{~cm})$ as well as no.of branches/plant (24.85 and 23.20) in both kharif and rabi seasons in tomato with OSV-5 $\left(\mathrm{T}_{9}\right)$. OPV-3 $\left(\mathrm{T}_{4}\right)$ recorded significantly higher Chlorophyll-a content $(1.53 \mathrm{mg} / \mathrm{g}$ and $1.59 \mathrm{mg} / \mathrm{g})$ and maximum total chlorophyll content $(2.66 \mathrm{mg} / \mathrm{g}$ and 2.55 $\mathrm{mg} / \mathrm{g}$ ) in both kharif and rabi seasons. In case of chlorophyll$\mathrm{b}$ maximum content $(1.57 \mathrm{mg} / \mathrm{g}$ and $1.51 \mathrm{mg} / \mathrm{g})$ recorded with OSV-1 $\left(\mathrm{T}_{5}\right)$. They also noticed maximum number of fruits per plant (94.24 and 79.85), maximum fruit yield per plant (3.90 $\mathrm{kg}$ and $3.47 \mathrm{~kg}$ ), maximum fruit yield per plot $(66.08 \mathrm{~kg}$ and $53.74 \mathrm{~kg}$ ) in both kharif and rabi seasons with OSV-5 ( $\left.\mathrm{T}_{9}\right)$.

Maria et al. (2016) ${ }^{[33]}$ observed significantly higher plant height $(59.3 \mathrm{~cm})$, fresh weight of root, stems and leaves (6.2, 38.1 and $25.7 \mathrm{~g} /$ plant, respectively) and also dry weight of root, stems and leaves (2.1, 7.5 and $5.7 \mathrm{~g} /$ plant, respectively) of tomato cv. Magilsas found maximum with nano silica treatment. The minimum day required for anthesis (16) was recorded with micro silica. They also found significantly higher fruit yield (143.9 g/plant), higher fruit weight (13.8 g) and number of fruits per plant (10.2) with nano silica treatment.

\section{Biotic and abiotic stress}

Murillo et al.(2007) [37] investigated the effect of calcium silicate to the nutrient solution under salt stress on two legumes (Cowpea and Kidney bean) and noticed that in both the crops, salinity reduced growth variables but silicate supplementation partly overcome this growth reduction.

Carlos et al. (2009) ${ }^{[6]}$ noticed the effect of silicon application and water deficit on potato and found higher Si concentration on potato leaves $(0.47 \%)$, reduction of stem lodging $(36.8 \%)$, increased mean tuber weight $(36.0 \mathrm{~g})$ and tuber yield (1014.6 g/plant).

Sharifa (2015) ${ }^{[40]}$ observed that silicon at different level (1 $\mathrm{mM}, 2 \mathrm{mM}$ and $3 \mathrm{mM}$ ) alleviated the harmful effect of $\mathrm{Cd}$ and $\mathrm{Pb}$ supplemented with different concentrations $(0,5,50$ and $100 \mathrm{mM} / 1$ for $\mathrm{Cd}$ and 50,500 and $1000 \mathrm{mM} / \mathrm{l}$ for $\mathrm{Pb}$ ) on germination and growth of faba bean.

Torlon et al. (2016) ${ }^{[46]}$ found that the percent of leaf area covered by powdery mildew in Pumpkin tended to be lowest at 63 DAS (4\%) and at 71 DAS (55\%) with Wollastonite. However, among from other amendments, Montana Grow also recorded the lower leaf area by powdery mildew at 68 DAS $(40 \%)$.Both these amendments also recorded the lowest percent of powdery mildew at 65 DAS, 67 DAS and 70 DAS (17, 32, and $40 \%$, respectively).

\section{Conclusion}

The supplementation of Silicon with nutrient element to the vegetable crops play a vital role for significant increase in growth, yield and quality. Silicon application also resulted in increase the productivity by act as defense system and thereby neutralizing the extremities of various biotic and abiotic stresses. Silicon plays significant roles in the growth and development as well as acts as a defense system thereby neutralizing the extremities of various biotic and abiotic 
stresses. Despite of this, Si has not received the attention it requires. Hence it is the need of hour to proceed wider and bring together not just strictly plant physiological evidence but to include findings and experiences gathered by botanists, agronomists, horticulturists, plant pathologists, plant biochemists and still others. There is no justification for the disregard of $\mathrm{Si}$ in so much science of plant biology. The evidence is forcing that in the real world of plant life, the presence and role of Si matters.

\section{References}

1. Ahmed Hassen FU, Qadeer U, Aslam MA. Silicon application and drought tolerance mechanism of sorghum. Afr. J. Agric. Res. 2011; 6(3):594-607

2. Anderson DL, Jones DB, Snyder GH. Response of a ricesugarcane rotation to calcium silicate slag on everglades Histosols. Agron J. 1987; 79:531-535

3. Bazilevich NI. The Biological productivity of North Eurasian ecosystems. RAS Institute of Geography, Nayka, Moscow, 1993.

4. Balint J, Csomor Z, Penzes B, Fail J. Lucrari Stiintifice, 2010; 54:22-30.

5. Brecht ML, Datnoff LE, Kucharek T, Nagata R. Effect of silicon and chlorothalonil on Suppression of gray leaf spot in St. Augustinegrass. Phytopathology. 2001; 91:S11

6. Carlos AC, Adriano LP, Leandro B, Rogerio PS, Giuseppina PP. Crop. Sci. 2009; 49:949-954

7. Cherf M, Menzies JG, Ehret DL, Bopgdanoff C, Belanger RR. Yield of cucumber infected with Pythium aphanidermatum when grown with soluble silicon. Hortic Sci. 1994; 29:896-897

8. Datnoff LE, Rutherford BA. Accumulation of silicon by bermudagrass to enhance disease suppression of leaf spot and melting out. USGA Turfgrass Environ Res Online. 2003; 2(18):1-6

9. Datta NP, Shinde JE. Yield and nutrition of rice under upland and waterlogged conditions. Effect of nitrogen, phosphorus and silica. J. Indian Soc Soil Sci. 1985; 33:53-60.

10. Elawad SH, Green VE. Silicon and the rice plant environment:a review of recent research. II Riso. 1979; 28:235-253.

11. Epstein E. The anomaly of silicon in plant biology. Proc Natl Acad Sci USA. 1994; 91:11-17

12. Epstein E. Silicon. Ann Rev Plant Physiol Mol Biol. 1999; 50:641-664

13. Esan K. Plant anatomy. Wiley, New York, 1953.

14. Gascho GJ. Silicon sources for agriculture. In: Datnoff LE, Snyder GH, Korndorfer GH (eds) Silicon in agriculture. Elsevier, Amsterdam, 2001, 197-207.

15. Gong HJ, Chen KM, Chen GC, Wang SM, Zhang CL. Effect of silicon on growth of wheat under drought. J Plant Nutr. 2003; 26(5):1055-1063

16. Gowda DC, Lingaiah HB, Nachegowda V, Kumar S. Pl. Archives. 2015; 15(1):335-338.

17. Hattori T, Inanaga S, Araki H, An P, Mortia S, Luxova M et al. Application of silicon enhanced drought tolerance in Sorghum bicolor. Physio Plantarum. 2005; 123:459466

18. Hodson MJ, White PJ, Mead A, Broadley MR. Phylogenetic variation in the silicon composition of plants. Ann Bot., 2005; 96:1027-1046

19. Inanaga S, Okasaka A, Tanaka S. Does silicon exist in association with organic compounds in rice plant? Japan J Soil Sci Plant Nutr. 1995; 11:111-117.
20. Islam A, Saha RC. Effect of silicon on the chemical composition of rice plants. Plant Soil. 1969; 30:446-458.

21. Jaywardana HARK, Weerahewa HLD, Saparamadu, M.D.J.S. (2014). Int. J. Multi. Studies. 1969; 1(1):33-39.

22. Jing-Kai L, Shi-qi L, Feng L, Chen X, Xue X, Cheng B et al. Pl. Nutri.Frt. 2014; (4):989-997.

23. Kamal AM. J.Pl. Prod. Mansoura Univ. 2013; 4(11):1581-1597.

24. Kaya C, Tuna L, Higgs D. Effect of silicon on plant growth and mineral nutrition of maize grown

25. under water-stress conditions. J Plant Nutr. 2006; 29:1469-1480.

26. Klepper B. Root-shoot relationships. In: Waisel Y, Eshel A, Kafkafi U (eds) Plant roots: the hidden half. Marcel Dekker, New York, 1991, 265-286.

27. Korndo GH, Lepsch I. Effect of silicon on plant growth and crop yield. Studies in plant science. Elsevier, Amsterdam, 2001, 133-147.

28. Korndorfer GH, Lepsch I. Effect of silicon on plant growth and crop yield. In: Datnoff LE, Snyder GH,

29. Korndorfer GH (eds) Silicon in agriculture. Studies in plant science. Elsevier,Amsterdam, 2001, 133-147.

30. Liang YC, Chen Q, Liu Q, Zhang WH, Ding RX. Exogenous silicon ( $\mathrm{Si}$ ) increases antioxidant enzyme activity and reduces lipid peroxidationin roots of saltstressed barley (Hordeum vulgare L.). J Plant Physiol. 2003; 160:1157-1164

31. Lux A, Luxova M, Hattori T, Inanaga S, Sugimoto Y. Silicification in sorghum (Sorghum bicolor) cultivars with different drought tolerance. Physiol Plantarum, 2002; 115:87-92

32. Ma J, Takahashi E. Effect of silicon on the growth and phosphorus uptake of rice. Plant Soil. 1990; 126:115-119

33. Ma JF. Function of silicon in higher plants. Prog Mol Subcell Biol. 1990; 33:127-147.

34. Marschner H. Mineral nutrition of higher plants. AcademicPress INC, San Diego, 1996.

35. Maria MDL, Diana MRD, Engelbert KP, Alvin NF, Milagros MP. Phillipine e- J. Applied Res. \& Dev, 2016, 10-18.

36. Matichenkov VV, Ammosova YM, Bocharnikova EA. The method for determination of plant-available silica in soil. Agrochem. 1997; 1:76-84

37. Matichenkov VV, Bocharnikova EA, Calvert DV, Snyder GH. Comparison study of soil silicon tatus in sandy soils of south Florida. Soil Crop Sci Soc Fla Proc. 2000; 59:132-137.

38. Mukhtar A, Asif M, Goyal A. Silicon the non-essential beneficial plant nutrient to enhanced drought tolerance in wheat crop plant. In: Goyal A (ed). http://www.intechopen.com/books/crop-plant/silicon-thenon-essential-beneficial-plantnutrientto- enhanceddrought-tolerance-in-wheat. Accessed May, 2013.

39. Olle M. $16^{\text {th }}$ World Fertilizer Congress of CIEC, Oral presentation papers, 2014, 90-92.

40. Raid RN, Anderson DL, Ulloa MF. Influence of cultivarand amendment of soil with calcium silicate slag on foliar disease development and yield of sugar-cane. Crop Prot. 1992; 11:84-88.

41. Sadanandan AK, Verghese EJ. Role of silicate in the uptake of nutrients by rice plants in the laterite soils of Kerala. Agric. Res. J. Kerala. 1969; 7:91-96.

42. Sharifa S. African J. Agric. Sci. \& Tech. 2015; 3(5):255268. 
43. Tisdale SL, Nelson WL, Beaton JD. Soil fertility and fertilizers. MacMillan Publisher, New York, 1985, 754.

44. Takahashi E, Miyake Y. Silica and plant growth. In:Proceedings international seminar on environment and fertility management in intensive agriculture (SEFMIA), Tokyo, Japan, 1977, 603-611

45. Takahashi E, Miyake Y. The effect of silicon on the growth of cucumber plant. In: Proceedings of 9th International plant nutr Collog Warwick Univ, UK, 1982, 669.

46. Takahashi E. Uptake mode and physiological functions of silica. Jpn J Soil Sci Plant Nutr. 1995; 49:357-360.

47. Thiagalingam K, Silva JA, Fox RL. Effect of calcium silicate on yield and nutrient uptake in plant growth on a humic ferriginous latosol. In: Proceedings of Conference on chemistry and fertility of tropical soils. Malaysian society of soil science, Kuallalumpur, Malaysia, 1977, 149-155.

48. Torlon JP, Heckmen JR, Simon JE, Wyenandt CA. Sustainability. 2016; 8(293):1-8

49. Wong YC, Heits A, Ville JD. Foliar symptoms of silicon deficiency in the sugarcane plant. Proc Congr Int Soc Sugarcane Technol. 1972; 14:766-776

50. Yoshida S. The physiology of silicon in rice. Food Fertilizer Tech. Centre Technical Bull. 1975, 25. 